\title{
THE NORTHERN TERRITORY EMERGENCY RESPONSE: The More Things Change, The More They Stay the SAME
}

\author{
NiCOLE WATSON*
}

The Northern Territory Emergency Response (NTER) was a raft of measures introduced by the Commonwealth of Australia in response to allegations of child sexual abuse in Northern Territory Aboriginal communities. The measures included the compulsory acquisition of Aboriginal lands, the quarantining of welfare payments, prohibitions on alcohol, and the vesting of expansive powers in the Commonwealth Minister to intervene in the affairs of Aboriginal organizations. This article aims to provide a brief historical background of Aboriginal people's experiences with the law in Australia, discuss certain provisions of the NTER, and, finally, examine the consequences three years after the implementation of the NTER. Through this analysis, the author suggests that history remains a powerful influence, resulting in the NTER being based on assumptions of Aboriginal people that are grounded in a racist past. Further, independent studies have shown that the NTER has been largely ineffective at accomplishing its stated objectives.
Le Northern Territory Emergency Response (NTER) était un ensemble de mesures introduites par le Commonwealth de l'Australie après des allégations de violence sexuelle à l'endroit des enfants des communautés autochtones des territoires. Les mesures incluaient l'obligation d'acquérir des terres autochtones, la mise en quarantaine des prestations de bien-être social, l'interdiction d'alcool et l'investissement de pouvoirs plus vastes au ministère du Commonwealth pour intervenir dans les affaires des organisations autochtones. Cet article vise à donner le contexte historique des expériences des peuples autochtones avec la loi en Australie, de discuter de certaines dispositions du NTER et enfin d'examiner les conséquences trois ans après la mise en œuvre du NTER. Au moyen de cette analyse, l'auteur laisse penser que l'histoire demeure une influence puissante, ayant pour résultat le fait que le NTER repose sur des hypothèses sur les Autochtones provenant d'un passé raciste. De plus, des études indépendantes ont démontré que le NTER a été essentiellement inefficace dans l'accomplissement des objectifs énoncés.

\section{TABLE OF CONTENTS}

I. InTRODUCTION . . . . . . . . . . . . . . . . . . . . . . . . . . . 905

II. ABORIGINAL PEOPLE'S HistoricAL

EXPERIENCES OF THE LAW . . . . . . . . . . . . . . . . . . . . 906

III. THE NORTHERN TERRITORY EMERGENCY RESPONSE $\ldots \ldots \ldots \ldots \ldots 910$

A. BACKGROUND ............................ 910

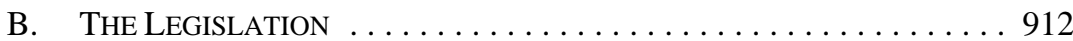

IV. REPERCUSSIONS OF THE NORTHERN TERRITORY

EMERGENCY RESPONSE . . . . . . . . . . . . . . . . . . . . . . . 915

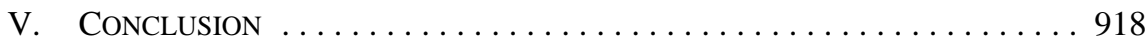

\section{INTRODUCTION}

On 13 February 2008, Australia’s former Prime Minister, Kevin Rudd, made an historic apology to the "Stolen Generations" (the Apology). The Stolen Generations are Aboriginal and Torres Strait Islander people who were removed from their families, as children, by Australian governments throughout the twentieth century. Many of those children grew up

Nicole is an Aboriginal lawyer from Queensland, Australia. She is a research fellow at the Jumbunna Indigenous House of Learning, University of Technology, Sydney. She has published work on the Northern Territory Emergency Response and is currently writing a textbook that will incorporate Indigenous content into Australian Law School Curriculums. 
in ignorance of their heritage. Abuse in state care was common, and to this day many continue to suffer the harmful effects of institutionalization. ${ }^{1}$

Rudd expressed contrition for laws and policies that had caused "profound grief," and the "indignity and degradation thus inflicted on a proud people." ${ }^{2}$ He was adamant that the "injustices of the past must never, never happen again." ${ }^{3}$ The author was privileged to witness the Prime Minister's speech firsthand. It was difficult not to be moved by his apparent sincerity and the emotive applause by some members of the Stolen Generations, who had travelled to Canberra for the event. Television footage and newspaper coverage were replete with images of people weeping in public places, their faces carrying expressions that ranged from exhilaration to relief. Commentators both within and outside Australia interpreted the speech as a defining moment in our history and a leap towards national maturity.

But there was also a sense of irony. Only the day before, Aboriginal people and their supporters rallied outside the Parliament to demand an immediate end to the Northern Territory Emergency Response (NTER). The NTER was a raft of measures introduced by the Commonwealth in August 2007, in response to allegations of child sexual abuse in Northern Territory Aboriginal communities. The measures included the compulsory acquisition of Aboriginal lands, the quarantining of welfare payments, prohibitions on alcohol, and the vesting of expansive powers in the Commonwealth Minister to intervene in the affairs of Aboriginal organizations.

This article will discuss one nexus between the historical injustices that Prime Minister Rudd referred to in the Apology and the NTER, which is the role of the law. In both instances, the law facilitated the regulation of a population stigmatized as lacking acceptable social norms. Australian Parliaments have a long tradition of enacting legislation for the purpose of coercing behavioural change in Aboriginal people. It is often preceded by a moral panic buttressed by racist mythology. Until Australian Parliaments abandon this tradition, gestures such as the Apology will achieve little towards reconciling the nation.

The article will proceed in three parts. Part II will provide a brief historical background of Aboriginal people's experiences of the law. Next, in Part III, provisions of the NTER that wrest autonomy from Aboriginal people into the hands of public servants will be discussed. Finally, in Part IV, the consequences of three years of the NTER will be examined.

\section{Aboriginal People’s Historical Experiences of the LaW}

Throughout Australia's history, Aboriginal people have occupied a unique position under the law. Although British subjects, they were considered to be so uncivilized that it was

Austl., Commonwealth, National Inquiry into the Separation of Aboriginal and Torres Strait Islander Children from Their Families, Bringing Them Home: Report of the National Inquiry into the Separation of Aboriginal and Torres Strait Islander Children from Their Families (Sydney: Human Rights and Equal Opportunity Commission, 1997).

2 Austl., Commonwealth, House of Representatives, Parliamentary Debates (13 February 2008 ) at 167. Ibid. 
assumed that they lacked even a rudimentary system of laws. Hence, there was no need to extend to them the protection of the rule of law.

In his judgment in Mabo v. Queensland, ${ }^{4}$ Brennan J. referred to an 1837 report to the House of Commons, which described Aboriginal people as "so entirely destitute ... of the rudest forms of civil polity, that their claims, whether as sovereigns or proprietors of the soil, have been utterly disregarded." " Until that watershed decision, Australian lawyers routinely believed that those who sailed into Port Jackson in 1788 entered a legal void, to be filled with English law exclusively. Such beliefs discarded any need for a treaty.

Aboriginal people's dubious status carried over to the criminal law. Doubts about whether or not the criminal law even applied to Aboriginal subjects were settled in R. v. Murrell. ${ }^{6}$ Jack Congo Murrell was an Aboriginal man charged with the murder of another Aboriginal man. One element of Murrell's defence was the argument that "natives" could not claim the protection of English law; it was not binding on them. The Supreme Court of New South Wales rejected his argument, stating that there was only one law in the Colony, and it was binding on all.

Nonetheless, Aboriginal people were precluded from giving evidence in criminal courts. There appear to be a number of reasons for the exclusionary rule, including language barriers, an impugned inability to comprehend English law, and the view that Aboriginal people did not subscribe to any religious belief in a higher being. This latter position was embraced by Judge Advocate Richard Atkins, who wrote that "the evidence of persons not bound by any moral or religious tye can never be considered or construed as legal evidence."7 The exclusionary rule facilitated the often violent dispossession of Aboriginal tribes because it accommodated a narrative that justified European retaliation. Europeans prosecuted for outrages against Aboriginal people successfully argued self-defence by appealing to perceptions of "troublesome" Aboriginals.

Whatever limited protection the law saw fit to provide to Aboriginal people was not in the nature of rights, but coercion. By the end of the first century of European occupation, Aboriginal people's inferior legal status found reflection in a series of Acts that comprehensively regulated their lives, under the misnomer of "protectionism.” Protectionism was fuelled by a number of forces, including humanitarian concerns over the plight of Aboriginal people who lived on the fringes of colonial society and, in particular, Aboriginal women who were vulnerable to sexual exploitation by unscrupulous Europeans. Protectionism was also a response to Christian concerns and public hysteria over miscegenation.

In her comprehensive history of Queensland's Aboriginal Affairs bureaucracy, Rosalind Kidd has drawn linkages between eighteenth century approaches to regulating England's

[1992] HCA 23, 175 C.L.R. 1.

U.K., Report of the Parliamentary Select Committee on Aboriginal Tribes, (British Settlements) (London: William Ball for the Aborigines Protection Society, 1837) at 125, cited in ibid. at 40.

[1836] NSWSupC 35.

Cited in Brent Salter, "Early Interactions Between Indigenous People and Settlers in Australia's First Criminal Court” (2009) 83 Austl. L.J. 56 at 59.

Salter, ibid. 
poor and the protectionist system. ${ }^{9}$ In the minds of British reformers, the poor had to be saved from criminality and depravity through indoctrination with the norms of industriousness and piousness. Poor children were placed into reformatories, where they were prepared for lives of menial labour. Parental consent was unnecessary.

British approaches found favour with colonial legislators in the Antipodes. The Industrial and Reformatories Schools Act of $1865^{10}$ sanctioned the removal of children who were found begging, living with a prostitute, or "born of an aboriginal or half-caste mother." ${ }^{11}$ Just over 30 years after the passage of that Act, the Queensland Parliament would enact the most influential and enduring model of Australian protectionist legislation: The Aboriginals Protection and Restriction of the Sale of Opium Act, $1897 .{ }^{12}$ This Act essentially created a form of wardship applicable only to Aboriginal people. Not all Aboriginal people were subject to the Act, but all were vulnerable to its grasp. Section 9 empowered the Minister to "cause any aboriginal" to be removed to a reserve. ${ }^{13}$ Once removed to a reserve, one was there indefinitely.

Most aspects of the reserve inmates' lives were subject to control by public servants, who brokered employment contracts on their behalf, managed their income, compelled them to undergo medical examinations, and even monitored their personal mail. ${ }^{14}$ Surveillance of inmates extended to the practice of tradition. "Protectors" were empowered to prohibit customs deemed injurious to the "peace and good order" of reserves. ${ }^{15}$

In common with English interventions, protectionist legislation evinced concern with the hygiene of inmates. For example, The Aboriginals Regulations of 1945 obliged reserve inmates to keep their homes "clean and tidy to the satisfaction of the protector." ${ }^{16}$ Moral hygiene was also important. In jurisdictions such as Queensland, Aboriginal women could not marry without official sanction. ${ }^{17}$ Likewise, in Western Australia it was illegal for any person, other than a "native," to cohabit with or have sexual relations with a "native" who was not that person's wife or husband. ${ }^{18}$

Inmates' salvation lay in industriousness, often procured through the enforcement of punitive sanctions. The Aborigines and Torres Strait Islanders Regulations of 1966 created offences against discipline that included "being idle, careless or negligent at work."19 Inmates’ work was often unremunerated. The Aboriginals Regulations of 1945 compelled inmates to perform up to 32 hours of unremunerated work per week in order to maintain what

Rosalind Kidd, The Way We Civilise: Aboriginal Affairs - The Untold Story (St. Lucia: University of Queensland Press, 1997).

(Vic.).

Ibid., s. 6(7).

(Qld.).

Ibid.

Chris Cunneen, Conflict, Politics and Crime: Aboriginal Communities and the Police (Crows Nest, Austl.: Allen \& Unwin, 2001) at 68.

The Aboriginals Preservation and Protection Act of 1939 (Qld.), s. 23.

(Qld.), s. 54.

Aboriginals Protection Act 1901 (Qld.), s. 9.

Native Administration Act 1905-1936 (W.A.), s. 46. For an analysis of this legislation, see Karen L. Whitney, "Dually Disadvantaged: The Impact of Anglo-European Law on Indigenous Australian Women” (1997) 4 James Cook University Law Review 13 at 28-33. (Qld.), s. 70(3)(b). 
were arguably their prisons. Those who refused unreasonably, "proof of which shall lie upon him," were deemed to have committed an offence. ${ }^{20}$

In spite of the enormous breadth of their powers, those who administered the legislation were subject to little scrutiny. Historians have revealed that decisions of great importance to inmates, such as exemption applications, were often determined according to the whims and prejudices of administrators. Thom Blake has referred to an application by one inmate for an exemption from the legislation, on the strength of his prior military service and lengthy work history. The application was refused because, in the opinion of one superintendent, he was "not a good type of native." 21

The lack of transparency in the administration of the protectionist regime meant that inmates often became exploited workers. The most common employment for Aboriginal women during the protectionist era was domestic service in white households. Aboriginal domestics frequently worked 15-hour days, lived in substandard conditions, and endured sexual harassment from their employers. ${ }^{22}$

Protectionism was eventually replaced by the policy of assimilation in the late 1930s. Assimilation shared certain commonalities with protectionism. In particular, implementation of the assimilation policy required surveillance of people who were still regarded as members of delinquent populations. Tony Birch described a visit by a welfare officer to the home of an Aboriginal family in Melbourne in 1948. The social worker described her client as "almost a Nordic type," but was assured that he was Aboriginal because he possessed "an aimless air about him, and seemed quite listless." 23

Aboriginal lives were also governed according to the personal whims of administrators in the Northern Territory, who compiled a list of wards. Once declared a ward, an individual was liable to be controlled under the Welfare Ordinance 1953-1960. ${ }^{24}$ Although the legislation appeared to be racially neutral, only Aboriginal people were entered on the list. Heather Douglas and John Chesterman have written about the case of Ruby Carew, a "full blood" Aboriginal woman who was married to a white man, Lance Carew. When Carew sought an exemption for his wife, her liberty came to depend upon the subjective views of those who administered the legislation:

In deciding the ward status of Mrs Carew, public relations officer Sweeney urged the Chief Welfare Officer to consider that when he had visited her home a week previously, Mrs Carew had several 'full-blood relatives' in the house with her and some in the yard outside. He noted that should anything happen to $\mathrm{Mr}$ Carew, she would return to those 'full-blood' relatives. On the other hand, some time earlier patrol officer Ryan had noted that Ruby had 'never caused any trouble', that Lance Carew was held in 'high repute', and that Ryan had recommended the marriage. ${ }^{25}$

Supra note 16, s. 28(2).

Thom Blake, A Dumping Ground: A History of the Cherbourg Settlement (St. Lucia: University of Queensland Press, 2001) at 137.

Ibid. at 132.

Tony Birch, “A Mabo Blood Test?” (1995) 6 The Australian Journal of Anthropology 32 at 32. (N.T.), Part III.

Heather Douglas \& John Chesterman, "Creating a Legal Identity: Aboriginal People and the Assimilation Census” (2008) 32 Journal of Australian Studies 375 at 384 [footnotes omitted]. 
In summary, for most of Australia's history Aboriginal people have occupied an inferior legal status, which has simultaneously deprived them of the protection of the rule of law while exposing them to a series of intrusive controls. Questions of pre-existing interests in the land were swept aside because Aboriginal people were considered so backward that they lacked any system of law. According to similar logic, Aboriginal people were not competent to give evidence as witnesses. For those subject to protectionism, everyday life and even questions of personal hygiene were governed by a series of Acts and Regulations. Transparency in administrative decision-making was nugatory, perhaps considered wasted on those who would possibly spend their entire lives as something less than adults with full legal capacity.

By the 1970s much of the legislative apparatus of the protectionist and assimilation eras had been, or was in the process of being, disbanded. On a political level, Australia was undergoing a transformation. The national consciousness was grappling with demands for sexual equality and opposition to the Vietnam War and South Africa's apartheid regime. For the first time, Aboriginal activists and their supporters touched the nation's conscience. The Whitlam Government embraced the policy of Aboriginal self-determination. Its successor, the Fraser Government, would later enact one of Australia's most successful land rights regimes, the Aboriginal Land Rights (Northern Territory) Act $1976 .{ }^{26}$

These milestones were followed by steps towards national maturity in the 1990s. In 1997, Australians were confronted by the revelations of Bringing Them Home, which documented the stories of hundreds of members of the Stolen Generations. It was also during this time that the Commonwealth Parliament committed to a process of national reconciliation, with the establishment of the Council for Aboriginal Reconciliation. ${ }^{27}$ In spite of such developments, however, the tradition of stigmatizing Aboriginal people as lawless and in need of control has remained, most recently manifest in the NTER.

\section{THE NORTHERN TERRITORY EMERGENCY RESPONSE}

\section{A. BACKGROUND}

In the past decade, numerous reports have revealed the linkages between poverty in Aboriginal communities, trans-generational trauma, and heightened vulnerability to abuse. ${ }^{28}$ While such reports usually provided detailed recommendations, there was seldom the political will to commit adequate resources for implementation. This changed dramatically in mid-2006, with the proliferation of voyeuristic media reports about the alleged sexual abuse of Aboriginal children in the Northern Territory.

26 (Cth.) [Land Rights Act].

The Council was a statutory authority, established by the Council for Aboriginal Reconciliation Act 1991 (Cth.).

28 Audrey Bolger, Aboriginal Women and Violence: A Report for the Criminology Research Council and the Northern Territory Commissioner of Police (Darwin: Australian National University, 1991); Austl., Queensland, Department of Aboriginal and Torres Strait Islander Policy and Development, The Aboriginal and Torres Strait Islander Women's Task Force on Violence Report (Brisbane: Department of Aboriginal and Torres Strait Islander Policy and Development, 1999); Austl., New South Wales, Aboriginal Child Sexual Assault Taskforce, Breaking the Silence: Creating the Future: Addressing Child Sexual Assault in Aboriginal Communities in NSW(Sydney: New South Wales Attorney General's Department, 2006). 
In May 2006, the Northern Territory Crown prosecutor, Nanette Rogers, was interviewed on the ABC television program, Lateline. During the interview, Rogers described the rapes of Aboriginal babies and an Aboriginal father raping his daughter at knifepoint. ${ }^{29}$ Such graphic imagery of violence against children had rarely before been featured on Australian television. The following evening, the former Commonwealth Minister for Indigenous Affairs, Mal Brough, claimed on Lateline that pedophile rings were operating in Aboriginal communities in the Northern Territory. ${ }^{30}$ Within weeks, the issue had become a full-blown moral panic.

The Chief Minister of the Northern Territory, Clare Martin, responded to the publicity by establishing the Northern Territory Board of Inquiry into the Protection of Aboriginal Children from Sexual Abuse (Inquiry). The Inquiry’s report, Ampe Akelyernemane Meke Mekarle: "Little Children are Sacred," was publicly released in June 2007. ${ }^{31}$ It contained numerous allegations of child sexual abuse and painted a horrific picture of communities that were in the throes of addiction and dysfunction.

The Inquiry's 97 recommendations advocated a holistic response, by emphasizing the need for family support services, community education, employment, and housing. The importance of consulting with Aboriginal communities was explicit:

The thrust of our recommendations, which are designed to advise the Northern Territory Government on how it can help support communities to effectively prevent and tackle child sexual abuse, is for there to be consultation with, and ownership by the communities, of those solutions. The underlying dysfunctionality where child sexual abuse flourishes needs to be attacked, and the strength returned to Aboriginal people. ${ }^{32}$

While the Commonwealth accepted the Inquiry's picture of a crisis, it rejected its consultative approach out of hand. On 21 June 2007, Prime Minister Howard and Minister Brough announced their plan to address this "national emergency" in the Northern Territory. The plan comprised compulsory medical checks of children, the seizure of Aboriginal lands, the quarantining of welfare payments, and the prohibition of alcohol and pornography. The military would also be sent into Aboriginal communities in an attempt to restore order. If the Commonwealth had to exercise its constitutional muscle and overrule Northern Territory laws, then so be it. As stated by Howard:

We are dealing with children of the tenderest age who have been exposed to the most terrible abuse from the time of their birth, virtually....

For a transcript of the interview, see "Crown Prosecutor speaks out about abuse in Central Australia" Lateline (15 May 2006), online: Australian Broadcasting Corporation <http://www.abc.net.au/lateline/ content/2006/s1639127.htm>.

30

31

32

For a transcript of the interview, see "Paedophile rings operating in remote communities: Brough" Lateline (16 May 2006), online: Australian Broadcasting Corporation <http:/www.abc.net.au/lateline/ content/2006/s1640148.htm>.

Austl., Northern Territory, Northern Territory Board of Inquiry into the Protection of Aboriginal Children from Sexual Abuse, Ampe Akelyernemane Meke Mekarle: “Little Children Are Sacred” by Rex Wild \& Patricia Anderson (Darwin: Northern Territory Government, 2007) [Little Children Are Sacred]. Ibid. at 21. 
It is interventionist, it does push aside the role of the territory to some degree - I accept that. But what matters more: the constitutional niceties, or the care and protection of young children? ${ }^{33}$

\title{
B. THE LEGISLATION
}

The legislative package that underpinned the NTER spanned almost 500 pages, and yet there was not a skerrick of consultation with those who would be forced to live under it. ${ }^{34} \mathrm{On}$ 9 August 2007, the legislation was referred for an inquiry to the Senate Standing Committee on Legal and Constitutional Affairs, whose report was due a few days later. ${ }^{35}$ The legislation was passed into law on 17 August 2007.

In his second reading of the Northern Territory National Emergency Response Bill 2007 in the Commonwealth Parliament, Brough painted Aboriginal communities as war zones, where standards of common decency had been discarded long ago:

\begin{abstract}
When confronted with a failed society where basic standards of law and order and behaviour have broken down and where women and children are unsafe, how should we respond? Do we respond with more of what we have done in the past? Or do we radically change direction with an intervention strategy matched to the magnitude of the problem?
\end{abstract}

Six weeks ago, the Little children are sacred report commissioned by the Northern Territory government confirmed what the Australian government had been saying. It told us in the clearest possible terms that child sexual abuse among Aboriginal children in the Northern Territory is serious, widespread and often unreported, and that there is a strong association between alcohol abuse and sexual abuse of children.

With clear evidence that the Northern Territory government was not able to protect these children adequately, the Howard government decided that it was now time to intervene and declare an emergency situation and use the territories power available under the Constitution to make laws for the Northern Territory. ${ }^{36}$

In spite of the Minister's emphasis on children, the Northern Territory National Emergency Response $\mathrm{Act}^{37}$ is not overtly concerned with child protection. Rather, the legislation attempts to protect children by enlarging the role of the state in both community governance and the daily lives of those who live on Aboriginal lands in the Northern Territory. It is beyond the scope of this article to provide a comprehensive analysis of the legislation in its entirety. Consequently, this article will identify some key provisions.

Adam Gartrell \& Tara Ravens, “Alcohol, porn ban to stop abuse” news.com.au (21 June 2007), online: news.com.au <http://www.news.com.au/alcohol-porn-ban-to-stop-abuse/story-e6frfkp9-1111113795 913>.

34 Social Security and Other Legislation Amendment (Welfare Payment Reform) Bill 2007 (Cth.); Northern Territory National Emergency Response Bill 2007 (Cth.); Families, Community Services and Indigenous Affairs and Other Legislation Amendment (Northern Territory National Emergency Response and Other Measures) Bill 2007 (Cth.).

35 Austl., Commonwealth, Senate Standing Committee on Legal and Constitutional Affairs, Social Security and Other Legislation Amendment (Welfare Payment Reform) Bill 2007 and four related bills concerning the Northern Territory National Emergency Response (Canberra: Commonwealth of Australia, 2007) at 2-3. 
Consistent with the Minister's portrayal of a "failed society," the legislation has an emphasis on law and order. Blanket prohibitions on alcohol ${ }^{38}$ and pornography ${ }^{39}$ were introduced, together with compulsory auditing of publicly funded computers. ${ }^{40}$ The brief of the Australian Crime Commission, a body ordinarily associated with the investigation of large-scale and organized crime, was expanded to include "Indigenous violence or child abuse." 41

It was not only communities that had “failed.” Individuals would be subject to daily regulation via an income management regime, which paints all Aboriginal people as incapable of managing their meagre welfare payments. Fifty percent of income support payments and 100 percent of lump sum payments are quarantined for expenditure on essentials. Quarantined funds may only be utilized by way of a debit card, which in turn can only be used at licenced stores.

The income management regime was applied on the basis of physical presence in a

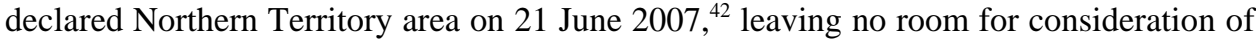
individual circumstances. The rationale for a blanket approach was provided by Brough in his second reading of the Social Security and Other Legislation (Welfare Payment Reform) Bill 2007, who once again conjured imagery of a society lacking standards of common decency:

The welfare reforms outlined in this bill will help to stem the flow of cash going towards substance abuse and gambling and ensure that funds meant to be for children's welfare are used for that purpose.

This broad-based approach is needed to address a breakdown in social norms that characterises many of our remote Northern Territory communities.

In particular, this approach is essential to minimize the practice known as 'humbugging' in the Northern Territory, where people are intimidated into handing over their money to others for inappropriate needs, often for alcohol, drugs and gambling.

If certain groups, such as the young and old, are excluded from this measure, it could leave them potentially even more vulnerable. ${ }^{43}$

Perhaps the most surprising aspect of the legislation, because of the absence of an obvious link between land and child protection, was its concern with control over Aboriginal land. The Commonwealth's powers to acquire Aboriginal lands are contained in Part 4 of the

Families, Community Services and Indigenous Affairs and Other Legislation Amendment (Northern Territory National Emergency Response and Other Measures) Act 2007 (Cth.), Sch. 1 [Emergency Response and Other Measures Act].

$40 \quad$ Emergency Response Act, supra note 37, Part 3.

$41 \quad$ Emergency Response and Other Measures Act, supra note 39, Sch. 2, Part 1, Division 1.

42 Social Security and Other Legislation Amendment (Welfare Payment Reform) Act 2007 (Cth.), Sch. 1, Pocial Security and Other Legislation

43 Parliamentary Debates, supra note 36 at 6 
Emergency Response Act. Section 31(1) provides that leases over certain Aboriginal lands are granted to the Commonwealth. The commencement dates of the leases vary, but all are to end five years after the commencement of s. $31 .^{44}$ Aboriginal land holders have few of the rights ordinarily enjoyed by lessors at common law. In particular, the power to terminate a lease.

At the same time, the Commonwealth loosened community control over access to Aboriginal lands. Historically, access to land held under the Land Rights Act required a permit from the relevant Aboriginal land trust that held title to the land. As a result of provisions of the Emergency Response and Other Measures Act, the permit system was weakened. In his second reading of the Bill, Brough said:

\begin{abstract}
The permit system for people entering Aboriginal land will be retained but permits will no longer be needed to access common areas in the main townships and the road corridors, barge landings and airstrips connected with them.
\end{abstract}

The current permit system has not prevented child abuse, violence or drug and alcohol running. It has helped create closed communities which can, and do, hide problems from public scrutiny. ${ }^{45}$

Aboriginal leaders and members of the police force expressed concern that changes to the permit system would be either ineffective or counterproductive. In its submission to the Senate Inquiry, the Police Federation of Australia said that

\begin{abstract}
[o]perational police on the ground in the Northern Territory believe that the permit system is a useful tool in policing the communities, particularly in policing alcohol and drug-related crime. It would be most unfortunate if by opening up the permit system in the larger public townships and the connecting road corridors as the Government intends, law enforcement efforts to address the 'rivers of grog', the distribution of pornography, and the drug running and petrol sniffing were made more difficult. ${ }^{46}$
\end{abstract}

But like the measured recommendations contained in Little Children Are Sacred, the Police Federation's concerns were ignored.

Part 5 of the Emergency Response Act vests broad powers in the Minister to intervene in the affairs of "community services entit[ies]" in "business management area[s]." Both terms are defined so broadly that it is possible the Minister could exercise their powers in relation to virtually any organization that was providing a service to an Aboriginal community in the Northern Territory. ${ }^{47}$ The Minister may direct a community services entity to provide a service in a specified way, ${ }^{48}$ use its assets in a particular way, ${ }^{49}$ or even transfer ownership

Supra note 37, s. 31(2)(b). Section 2 provides that s. 31 commenced on 18 August 2007.

Parliamentary Debates, supra note 36 at 20.

Letter from Mark Burgess, Chief Executive Officer, Police Federation of Australia, to the Secretary, Senate Standing Committee on Legal and Constitutional Affairs, "Submission Regarding the Northern Territory (National Emergency Response) Bill 2007 and Associated Bills” (9 August 2007) at 3, online: Parliament of Australia (Department of the Senate) < http://www.aph.gov.au/senate/committee/legcon_ ctte/completed_inquiries/2004-07/nt_emergency/submissions/sub24.pdf>.

Supra note 37, s. 3.

Ibid., s. 67(2)(b).

Ibid., s. 68(2)(a). 
of its assets to a person or entity determined by the Minister. ${ }^{50}$ The Minister may also appoint observers to a community services entity, ${ }^{51}$ who are entitled to attend the meetings of the community services entity. ${ }^{52}$

At the same time, the legislation deprived Aboriginal people of protection under antidiscrimination legislation. By way of example, s. 132(1) of the Emergency Response Act provides that the provisions of the legislation and acts done under the legislation are "special measures" ${ }^{53}$ for the purposes of the Racial Discrimination Act $1975 .{ }^{54}$ In essence, a special measure is a form of positive discrimination that has the aim of securing the advancement of a disadvantaged group, and therefore is permissible under the Racial Discrimination Act. However, in order to ensure the validity of the legislation, the operation of the Racial Discrimination Act was expressly excluded as well. ${ }^{55}$

In summary, there are a number of similarities between elements of the NTER and the historical experiences described in Part II, above. In common with protectionist legislation, the NTER was preceded by a moral panic. Aboriginal people were perceived to be so barbarous that they were deemed incapable of protecting and nurturing their own children. In common with earlier Australian Parliaments, the Commonwealth responded with invasive legislation that strikes at the heart of community life and regulates the daily lives of individuals. At the same time, Aboriginal people were deprived of rights enjoyed by other Australians, particularly the ability to seek relief under the Racial Discrimination Act.

\section{REPERCUSSIONS OF THE NORTHERN TERRITORY EMERGENCY RESPONSE}

In the past two years, the NTER has been subject to one official review and analysis by experts in fields such as medicine and law. This work has revealed that while the NTER has yielded some minor gains, it has largely failed to deliver a transformation in social norms. If anything, individuals and communities are increasingly suffering the strain of a top-down approach that denies them autonomy.

In June 2008, the Commonwealth appointed a Review Board (Board) to assess the first year of the NTER. The Board visited 31 Aboriginal communities throughout the Northern Territory and received over 200 submissions, the majority of which called for either the dismantling or substantial reform of the NTER. ${ }^{56}$ When it reported in October, the Board identified some positive outcomes of the NTER, such as an increased police presence in areas that had previously been neglected by law enforcement. However, the Board also described a "strong sense of injustice" on the part of many Aboriginal people who were unfairly painted as the authors of their own poverty. ${ }^{57}$ Such frustration resounded in the

Ibid., s. 68(2)(d).

Ibid., s. 72(1).

Ibid., s. 72(2).

Ibid.

(Cth.) [Racial Discrimination Act].

Emergency Response Act, supra note 37, s. 132(2).

Austl., Commonwealth, Northern Territory Emergency Response Review Board, Northern Territory Emergency Response: Report of the NTER Review Board by Peter Yu, Marcia Ella Duncan \& Bill Gray (Canberra: Commonwealth of Australia, 2008) at 9.

Ibid. 
submission of the Australian Indigenous Doctors' Association, which revealed that the NTER had “created a feeling of 'collective existential despair' ... characterised by a widespread sense of helplessness, hopelessness and worthlessness, and experienced throughout entire communit[ies]."

The Board's report suggested that there was a gulf between the "failed society" rhetoric and implementation on the ground. The pornography provisions were so difficult to enforce that only one matter had ended up in court, and signage declaring the alcohol and pornography prohibitions, erected at significant expense, was incomprehensible for people whose first language was not English. ${ }^{59}$ One of the most significant revelations was that "most communities reported little or no perceived change in the safety and wellbeing of Aboriginal children as a result of the NTER."60 Indeed, Aboriginal children appeared to have gained little from the NTER. Local health service providers reported that child health checks, introduced as a part of the NTER, duplicated existing services and represented a wasted opportunity. ${ }^{61}$

The NTER Review Board considered the situation in Aboriginal communities sufficiently dire for the NTER to continue. But it called for the Commonwealth to "reset" its relationships with Aboriginal communities, based on "genuine consultation, engagement and partnership.”62 The Board also considered that all government actions should be consistent with Australia's human rights obligations, in particular the Racial Discrimination Act. ${ }^{63}$

The Commonwealth failed to engage with much of the Board's report. In common with her predecessor, the new Minister for Indigenous Affairs, Jenny Macklin, continued to depict Aboriginal people as being in need of control. In rather cryptic language, Macklin announced that the "current stabilisation phase of the NTER" would "continue for the next twelve months before transitioning to a long-term, development phase.” ${ }^{64}$ The "development phase" of the NTER would begin "when increased levels of personal and community responsibility are demonstrated.”65

In May 2009, the Commonwealth released a discussion paper, in which it was claimed that the NTER was delivering substantial improvements, especially in the nature of increased household expenditure on essential items. It was also argued in the same discussion paper that the NTER could be recalibrated in order to achieve consistency with the Racial Discrimination Act. ${ }^{66}$ The following month, the Commonwealth conducted widespread community consultations in relation to a proposed redesign of the NTER.

Australian Indigenous Doctors' Association, Submission to the Northern Territory Emergency Response Review Board (Canberra: Australian Indigenous Doctors’ Association, 2008) at 7.

Yu, Duncan \& Gray, supra note 56 at 25.

Ibid. at 34 .

Ibid. at 36.

Ibid. at 12 .

Ibid.

The Hon. Jenny Macklin MP, Media Release, "Compulsory income management to continue as key NTER measure" (23 October 2008), online: The Hon. Jenny Macklin MP < http://www.jennymacklin. fahcsia.gov.au/mediareleases/2008/Pages/nter_measure_23oct08.aspx $>$.

Ibid.

66 Austl., Commonwealth, Future Directions for the Northern Territory Emergency Response: Discussion Paper (Canberra: Commonwealth of Australia, 2009) at 7. 
The consultations attracted the criticism that they were an attempt to sell the predetermined views of the Rudd Government. Listening to the voices of Aboriginal people affected by the NTER was an ancillary concern. Such criticism found reflection in the independent report, Will They Be Heard ${ }^{67}$ The report referred to statements of government representatives at community meetings to the effect that the Commonwealth had already decided to maintain the NTER. ${ }^{68}$

The report also identified numerous deficiencies in the manner in which consultations were conducted. Participants who spoke no English at all, or spoke English only as a second language, were denied access to interpreters. ${ }^{69}$ Complex legal concepts also appeared to have been deliberately simplified in order to garner support for the government's position. ${ }^{70}$ In spite of such impediments to effective participation, many expressed strong opposition to the NTER. There was a common perception that few improvements had been made on the ground and that entire communities had been stigmatized as perpetrators of child sexual abuse. ${ }^{71}$ There was also a belief that the NTER represented a return to the previous era:

I mean this goes back to, I am sorry, but back in the time when you had Native Affairs where the government was overruling people and then you've got it, it is now 40 years down the track now, 50 years down the track. I was there in Native Affairs time, and this is exactly what they are doing to us now. ${ }^{72}$

In spite of such opposition at the grass roots, the Rudd Government chose to persevere with the NTER.

A Health Impact Assessment of the NTER by the Indigenous Doctors’ Association last year predicted that the intended health outcomes of the NTER were unlikely to be achieved because of its negative impacts on psychological and social well-being. ${ }^{73}$ Once again, the past found resonance in how the NTER was being experienced on the ground:

\footnotetext{
Throughout the conduct of the HIA, community members and stakeholders expressed shock, frustration, shame and anger at the discriminatory, racist nature of the NTER - calling up, for most people, memories and experiences of trauma that had been experienced by their families and communities for generations, and by themselves. Many people had thought that the days in which governments would act in this way had passed, that their democratic rights as citizens of Australia were secure. ${ }^{74}$
}

Today the Commonwealth government's support for the NTER remains unwavering, even in the face of the government's own statistics, which have revealed increases in rates of child

Alastair Nicholson et al., Will They Be Heard?: A Response to the NTER Consultations - June to August 2009 (Sydney: Jumbunna Indigenous House of Learning, 2009).

Ibid. at 24.

Ibid. at 23.

Ibid. at 27.

Ibid.

Ibid. at 25.

Australian Indigenous Doctors' Association and Centre for Health Equity Training, Research and Evaluation, Health Impact Assessment of the Northern Territory Emergency Response (Canberra: Australian Indigenous Doctors' Association, 2010) at ix.

Ibid. at 14 . 
malnutrition, mental illness, and attempted suicide. ${ }^{75}$ The repercussions for Aboriginal people are disturbingly similar to those recorded by historians in relation to protectionism and assimilation. Invasive legislation that regulates a people who are already stigmatized is a massive assault on their humanity. This wound is so deep, so encompassing, that its longterm effects on the psyches of those afflicted are likely to be extreme.

\section{CONCLUSION}

In Australia, Aboriginal people's experiences of the law have been a tension between inadequate protection and excessive regulation. At the heart of this tension is racism. Historically, Aboriginal people were considered so barbarous they were not capable of possessing rights. Aboriginal people were in such desperate need of regulation that Australian Parliaments bestowed upon them a form of wardship under the misnomer of protectionism. For the greater part of the twentieth century, protectionism and then assimilation dehumanized individuals and tore the fabric of Aboriginal family life.

That history remains a powerful influence today, as evidenced by the NTER. Once again, Aboriginal people have been stigmatized as morally deficit and in need of control. In little over three years, the psychological harm occasioned by the NTER has begun to rear its head. But what of Australia's parliamentarians and, in particular, those who professed to share the sentiments of the Apology on 13 February 2008? What are the consequences for national reconciliation? Perhaps Patrick Dodson put it best when he said:

As long as even one such regime of social oppression remains in place in this country, we remain a subjugated people. As long as a Parliament is able to remove some of our most basic rights on a political whim, we remain a subjugated people. If governments, newly elected, retain those same impediments to justice when all the evidence available tells them that the programmes and strategies emanating from the oppression are failing to deliver the asserted outcomes, then reconciliation is no longer a national aspiration. It is a ruse to disguise our continued subjugation. ${ }^{76}$

Jon Altman, "NT intervention three years on; government’s progress report is disturbing” Crikey (21 June 2010), online: Crikey <http://www.crikey.com.au/2010/06/21/nt-intervention-three-years-ongovernments-progress-report-is-disturbing/>.

76 Patrick Dodson, "Can Australia afford not to be Reconciled" (Keynote address delivered at the National Indigenous Policy and Dialogue Conference, Sydney, 19 November 2010) at 4, online: Indigenous Policy \& Dialogue Research Unit < http://www.ipdru.arts.unsw.edu.au/media/File/Dodson_keynote.pdf> [emphasis omitted]. 